\title{
Expanding normative ways of reflective thinking and enthusiastic behaviors towards teaching profession
}

\author{
Muhlise Coşkun Ögeyik \\ Trakya University, Turkey / Contact: muhlisecosgun@ @rakya.edu.tr
}

\begin{abstract}
Performing reflective procedures is among the attempts to improve the quality of professional development in teacher training process. Reflective procedures are assumed to be functional for increasing normative ways of thinking and for encouraging student teachers to develop more enthusiastic attitudes towards teaching profession. Action research, among such procedures, is used to employ numerous teaching drills and to reflect on the teaching practice. Therefore, this study discusses the importance of action research in teacher training process for developing reflective thinking skills of student teachers and for fostering their enthusiastic attitudes towards professional development. In the study, action research was designed with the participation of the student teachers attending English Language Teaching Department at a Turkish university. The results of this small scaled study demonstrated that action research reasonably contributed to professional innovation and renovation of the student teachers, helped them reflect on their inner thoughts about the process, and increased their enthusiastic behaviors towards teaching practices.
\end{abstract}

(C) 2020 The Literacy Trek \& the Authors - Published by The Literacy Trek APA Citation

Ögeyik, M. C. (2020). Expanding normative ways of reflective thinking and enthusiastic behaviors towards teaching profession. The Literacy Trek, 6(2), 28-40.

https://doi.org/10.47216/literacytrek.775199

\section{Introduction}

Teachers are responsible for various tasks as well as teaching issues in the classroom. They are expected to have the authority of classroom management endowment, to build up a close relationship and rapport with students, to encourage students for learning, to increase motivation, to create a warm atmosphere in the classroom, and etc. Moreover, a teacher is responsible for conducting classroom research for creating further opportunities to observe their own students during the course and for formulating hypotheses on actual experiences (Bailey, 2001). Among 
the research types, action research is one of the widely employed classroom research procedures. Action research is a form of self-reflective and systematic enquiry that leads to improvement in practice and a collaborative act that promotes improvement in education (Stringer, 2007; Creswell, 2008; Borg \& Sanchez, 2014); thus, teachers can develop professionally by reflecting on their teaching by means of action research (Burns, 2014). Therefore, in this study, the significance of action research in teacher education process in terms of prompting reflective thinking and increasing enthusiasm is discussed.

\section{Professional development and reflective thinking through action research}

Professional development for teachers is an everlasting process through which they try to find new and alternative ways to develop their methods and techniques, pedagogical knowledge, teaching notions, strategies, and practices. Research studies on effective professional development of teachers suggest that professional development of teachers heavily depend on reflective teaching (Cochran-Smith, 2005; Borg, \& Sanchez, 2014; Kostaris et al. 2017). Action research that is a way of selfreflection provides teachers with opportunities to reflect on their teaching practice. Through reflection on teaching issues, teachers are involved in taking action systematically in order to better understand or enhance an aspect of teaching or learning (Burns, 2013). Action research as a group activity and a form of selfreflective inquiry (Kemmis \& McTaggert, 1998) may be viewed as a standpoint in which the teacher is engaged in the investigation of the outcome of the practice.

Methodologists have agreed upon a set of common characteristics of action research. For Dikilitaş and Yaylı (2018), action research offers opportunities to teachers to investigate the development of their professional identities and is a key professional development strategy for language teachers. Borg (2013) suggests that teachers who become action researchers are also engaged in the process of identity construction. Moreover, action research is acknowledged as an effectual means within pre-service and in-service education to develop professionally while teaching and operating in the classroom, school, and educational community (Kostaris et al., 2017). It is also claimed that action research is a way of developing practical decisions and judgments both by putting theoretical ideas into practice and by seeking answers to 
the problems (Nunan \& Bailey, 2009; Ryan, 2016). In the process, thus, teachers can get the opportunity of monitoring the effects of the action and try to observe whether any constructive changes appear in the teaching/learning process.

Scholars have defined the specific procedures of applying action research. Dörnyei (2007) emphasizes that collecting and interpreting data through follow-up actions involves a clear and repeated cycle of procedures in which the researcher begins by planning an action to address a problem, an issue, or a question in his or her own context. Cohen and Morrison (2000) outline eight stages of action research cycle as: identify the problem; develop a draft proposal based on discussion and negotiation between interested parties; review what has already been written about the issue in question; restate the problem or reformulate hypotheses; select research procedures, resources, materials, and methods; choose evaluation procedures; collect the data, analyze the data, and provide feedback to the research team; interpret the data, draw out inferences, and evaluate the project. After gathering the data and reflecting on the data, the data-driven decision directs the teacher to take some actions (Dörnyei, 2007) and may encourage them to look for further practical considerations.

Action research is the procedure to be implemented not only by novice or expert teachers but also by student teachers. Within pre-service education process, action research provides student teachers with opportunities of professional development, since they plan lessons, take action in pre-service classes, observe, and reflect on their experiences (Ryan, 2016). In some studies, for instance by Ado (2013), Jayakumar (2016), Mitits (2018), Mirzajani et al.(2016), action research is suggested for professional development of student teachers, since they become engaged in reflection on their practice and may make changes in their teaching actions.

Action research is also becoming increasingly popular in English Language Teaching and language teacher training contexts as a means of continuous professional development. It is claimed that the force of action and direct application of research to reflect on the action in language education can allow teachers to focus on their own practice in as systematic way (Burns \& Westmacott, 2018), and therefore, in the ELT world, action research is often used to solve local problems that teachers want to address (Brown, 2014) and to answer possible questions (Dikilitaş \& 
Griffith, 2017). It is declared that student teachers who have been exposed to action research tasks are found to increase high level of enthusiasm and self-confidence (Kiss, 2016; Davis, Clayton \& Broome, 2018; Vo, Pang \& Wah, 2018), since they have the responsibilities of evaluating their own teaching practice and reflecting on it.

\section{Increasing enthusiastic attitudes towards teaching profession}

As long as individuals are trained regarding their needs, expectations, background knowledge, motivation levels, cultural and social milieu from which they come, all those factors influence their enthusiastic attitudes during learning process (Brown, 2007; Dörnyei \& Ushioda, 2012). Those factors also shape student teachers' learning and teaching behaviors. In teacher training process, teachers' knowledge and beliefs are constructed through the normative ways of thinking, talking, and acting that have been historically and culturally embedded in communities of practice in which they participate; this means the normative ways of acting, the values, assumptions, and attitudes that are embedded in the classroom where teachers were once students and in the schools where they work, shape their students, design the activities of L2 teaching (Johnson, 2009); therefore, allowing student teachers to create their own teaching procedures and reflect on them in the classroom environment may expand the normative ways of thinking and may make them more enthusiastic for teaching profession.

Reflection on teaching is defined as a cyclical problem-solving process and as a metacognitive process that implies an awareness of what an individual does and thinks (Marcosa, Migula, \& Tillemab, 2009). In other words, as long as student teachers are engaged in reflection on their teaching practice, they may explore their inner thoughts about their teaching, increase enthusiasm for teaching profession, and thus, they become aware of their teaching performance. Through constant reflection on the changes, practical solutions to the problems can be offered (Dörnyei, 2007), since teachers committed to ongoing development and change are prepared to monitor the success of their teaching practices on a regular basis by recognizing that they themselves must be the judge of their own performance (Senior, 2006). To conclude the results of the reviewed studies, reflective procedures implemented through action research are functional for increasing student teachers' enthusiastic attitudes towards 
teaching profession. In this respect, the aim of this study is to report the implications of the action research project designed by the student teachers during teacher training process and to discuss whether the action research procedure affected their attitudes towards teaching profession as claimed in the relevant literature.

\section{Methodology}

Action research expected to increase enthusiasm in the classroom practice was designed in the Methodology course of a teacher training program in Turkey. Both qualitative and quantitative data collection and analysis procedures were used in the study. To collect the qualitative data, think aloud protocols to scrutinize the current thought processes and talk aloud protocols to inspect additional thoughts were used. To collect the quantitative data, a questionnaire was designed by the researcher. The qualitative data were reviewed and revisited many times during the data analysis process in order to allow the modifications of the preliminary conclusions. For quantitative data analysis, statistical programs were used. The Institutional Review Board approval was received on 2020, July, $22^{\text {nd }}$ for the current study.

\section{Participants}

The participants of the present study were the third year student teachers attending English Language Teaching -ELT- Department at a Turkish University. Twenty-six student teachers participated in the study. The participants were recruited from the same class. The action research procedure continued for six weeks.

\section{Data Analysis}

Action research steps in the present study were designed in the following order by adapting the model suggested by Cohen, Manion, and Morrison (2000).

Step 1 . Identify the problem

The action research cycle was initiated by identifying the problem "The student teachers' enthusiasm towards teaching issues began to decrease over time in the Methodology course."

Step 2. Design the action plan 
The action plan was designed by the involvement of the participants. They were encouraged to take part in the course design through investigation and discussion sessions. A six-week action plan was designed.

\section{Step 3. Action procedure}

In the methodology course, the student teachers were initially exposed to theoretical knowledge through lecture sessions, and then they were encouraged to put the theoretical knowledge into practice. Thus, it was presumed that they would gain insights about how to focus on the teaching issues, diagnose the possible problems, and find out solutions to the problems. At the end of the course sessions, they discussed the topic with their classmates.

\section{Step 4. Collect the data}

During the research process, think aloud and talk aloud protocols were used to learn about the participants' reflections on the action plan. Think aloud reports were collected in written form during the course time. Talk aloud reports were collected via 5-minute pen and paper reflection tools after six-week action research process. To verify the written think aloud and talk aloud data, a questionnaire developed by the researcher was administered to the participants.

\section{Step 5. The Reflective practice}

At the beginning of the research process, they had hesitations while reflecting their ideas in English, but they gradually felt themselves more comfortable and became more confident without having any hesitation for making errors or mistakes in oral tasks. The reflective practice in this study led to some modifications of the predesigned activities and learning materials regarding the student teachers' reflections. The student teachers' reflections were reported regularly, and when they had any troubles with any topic, solutions were sought with the participation of all class members. Such efforts led to collaborative and cooperative learning.

\section{Think aloud protocols, talk aloud protocols}

The reflections of the participants in the think aloud and talk aloud protocols were analyzed and classified in seven themes with seven corresponding categories. While categorizing the data, first of all each category was described clearly. The 
categories were designed in a consistent and logical relationship with the participants' responses. The categories were re-checked a few times in some intervals and the original data were re-visited to confirm the results and to set aside the individual perspective of the researcher. The researcher asked another colleague to interpret the original data and reflect on the categories. The colleague confirmed the analysis of the researcher. The reflections of the participants were categorized with the corresponding themes and narrated with the consistent keywords. The narrated items are displayed in Table 1.

Table 1. The themes and categories in think aloud and talk aloud protocols

\begin{tabular}{|c|c|c|c|}
\hline Theme & Category & Number of posts & Keyword \\
\hline $\begin{array}{l}\text { Attitude towards the } \\
\text { course content }\end{array}$ & Enthusiasm & 84 & $\begin{array}{l}\text { Teaching practice, enjoyable course, } \\
\text { clear explanations, lucid information, }\end{array}$ \\
\hline Classroom atmosphere & Enthusiasm & 83 & Creativity, autonomy, self-disciplined \\
\hline Teaching pace & $\begin{array}{l}\text { Professional } \\
\text { development }\end{array}$ & 67 & $\begin{array}{l}\text { Course design, lesson plan, course } \\
\text { activities, materials design }\end{array}$ \\
\hline $\begin{array}{l}\text { Self-efficacy and self- } \\
\text { esteem }\end{array}$ & Enthusiasm & 61 & $\begin{array}{l}\text { Warm, friendly, good relationship, } \\
\text { rejecting bias, feeling comfortable }\end{array}$ \\
\hline Reasonable knowledge & $\begin{array}{l}\text { Reflective } \\
\text { thinking }\end{array}$ & 54 & $\begin{array}{l}\text { New information, precise opinions, } \\
\text { comprehensible teaching issues, } \\
\text { interaction with others }\end{array}$ \\
\hline Task implementation & Enthusiasm & 47 & $\begin{array}{l}\text { Making decision on their own, } \\
\text { searching for the truth, finding } \\
\text { solutions to problems, }\end{array}$ \\
\hline Teaching competence & $\begin{array}{l}\text { Professional } \\
\text { development }\end{array}$ & 28 & $\begin{array}{l}\text { Applying knowledge to variety of } \\
\text { issues, reasonable feedback, giving } \\
\text { suggestions }\end{array}$ \\
\hline
\end{tabular}

As displayed in the table, they declared their high level of enthusiasm towards the course content. They posted their ideas through 84 episodes of keywords such as teaching practice, enjoyable and clear or lucid explanations in the course. Similarly, their high level of enthusiasm was reflected for the themes about classroom atmosphere, self-efficacy/self-esteem, and task implementation via total 191 posts (83, 61, 47 for the themes respectively). The reflection on enthusiasm was repeated totally 275 times via different key words as displayed in the table. In terms of professional development, they reflected their ideas about teaching pace and teaching competence through 67 and 28 posts respectively, totally 95 posts. For professional development they used such keywords as course design, lesson plan, course activities, materials design, reasonable feedback, giving suggestions, and etc. In reflective 
thinking, they declared their ideas 54 times on the issues such as getting new information, precise opinions, comprehensible teaching issues, interaction with others, and etc.

\section{Questionnaire}

In this study, another form of reflective inquiry was the use of questionnaires. The questionnaires comprised items about the benefits of the course in which action research was designed. They were also asked to judge the quality of the work. The participants' comments were evaluated with percentage values.

Table 2. Student teachers' reflections about the Methodology course designed with action research

\begin{tabular}{|c|c|c|c|}
\hline In the methodology course, I think & $\begin{array}{c}\text { agree } \\
\%\end{array}$ & $\begin{array}{c}\text { no idea } \\
\%\end{array}$ & $\begin{array}{c}\text { disagree } \\
\%\end{array}$ \\
\hline I was able to carry out my tasks more efficiently & 86 & 4 & 10 \\
\hline I was able to further my ideas & 72 & 3 & 25 \\
\hline I was aware of my personal development & 51 & 7 & 42 \\
\hline I took the control of my learning & 91 & 1 & 8 \\
\hline I liked integrating in classroom discussions & 96 & - & 4 \\
\hline I improved my proficiency in English during the classroom discussions & 86 & 5 & 9 \\
\hline I spoke in English during the course time without hesitation & 81 & 9 & 10 \\
\hline I could conduct teaching practice on my own & 55 & 17 & 28 \\
\hline I felt myself more autonomous & 90 & 2 & 8 \\
\hline I could freely reflect my ideas & 93 & 2 & 5 \\
\hline I could find solutions to the problems I faced & 67 & 15 & 18 \\
\hline I found the courses more enjoyable & 94 & - & 6 \\
\hline My creativity got increased in due course & 88 & 3 & 9 \\
\hline I learnt novel things day by day & 98 & 2 & - \\
\hline I shifted from passive learner to active learner & 73 & 12 & 15 \\
\hline I always looked forward the day when we had methodology courses & 88 & 10 & 2 \\
\hline I got rid of bad-tempered mood & 76 & 8 & 16 \\
\hline I was somehow anxious in the classroom & 19 & 9 & 72 \\
\hline I did not want to participate in discussion sessions due to my English & 16 & 10 & 74 \\
\hline I felt good because I know I did well & 72 & 20 & 8 \\
\hline I felt disappointed when I did nothing & 71 & 12 & 17 \\
\hline I gained self-confidence & 81 & 5 & 14 \\
\hline I liked interacting with my classmates & 95 & 5 & - \\
\hline $\begin{array}{l}\text { Being in collaborative and cooperative learning context increased my self- } \\
\text { efficacy }\end{array}$ & 88 & 2 & 10 \\
\hline
\end{tabular}


As displayed in table 2, the responses of the participants were mostly in positive manner. At the end of the action research process, the participants' responses demonstrated that most of them benefited from classroom activities in terms of task implementation, classroom discussions, carrying out group work, interactive involvement in the classroom procedures, being a member of cooperative and collaborative learning, and selection of appropriate course materials. Additionally, they believed they developed their English competency by participating in discussion sessions, although a few declared their hesitation because of their English level.

As for the feelings of the participants about the course, they declared that the course was enjoyable and they were eager to participate in the course tasks. Nearly all participants declared that they looked forward the day when they had the course, though a few were anxious in the classroom. More than half stated they felt disappointed when they did nothing. Most declared they became aware of their personal development by taking the control of their learning in an autonomous manner; they felt they were able to reflect their ideas freely and further their ideas on novel things they learnt. Thus, they believed they shifted from passive mood to active mood in the course by increasing their level of self-confidence and creativity. The overall responses of the participants displayed their enthusiasm in the course participation.

\section{Discussion and Suggestions}

In this study, action research was designed to assist the student teachers who lost enthusiasm towards the methodology course for professional development, to increase their interest, and to expand their reflective thinking capabilities. The findings of the study showed the benefits of engaging the student teachers in the action research process. Most of the participants had positive attitudes towards the classroom practice. They thought their own confidence level got increased throughout the process, and being an active member of the course motivated them to work eagerly. The student teachers became more enthusiastic and eager to work cooperatively and collaboratively with their classmates. 
In the discussion sessions, the participants voluntarily had an attempt to reflect their ideas on the theoretical issues. Thus, they also got the opportunity of oral practice in English; and in some occasions, when they could not continue discussions in English, they used their mother tongue, Turkish. During the discussion sessions, they created occasions for negotiating their ideas and getting feedback by both their classmates and the lecturer. Generally speaking, individual participation in discussions for reflecting their ideas and oral performance in English increased their awareness on the course topics and enthusiasm for teaching profession. Additionally, they could evaluate themselves properly. However, in some cases, the action plan was not implemented well due to a few reluctant participants. They experienced intragroup and intergroup difficulties.

As consistent with the studies in the literature such as by Burns (2013), Dikilitaş and Yaylı, (2018), Borg (2013), they learned a lot by thinking about the course topics and tried to develop professional identities. All the findings from this small scaled research project display that action research is a renew process for both students and teachers as well as a deep inquiry process in which innovation and renovation can be supplied through the self-reflection. In the studies such as Nunan and Bailey (2009), Ryan (2016), it was suggested that action research is a way of developing practical decisions and judgments by putting theoretical ideas into practice and by seeking answers to the problems. Comparable results were also obtained from this study. As the studies by Jayakumar (2016), Mitits (2018), Mirzajani et al.(2016) suggested, action research in this study was thought to be a type of professional development for the student teachers, since they engaged in reflection on their practice. Moreover, the literature suggests that student teachers who have been exposed to action research tasks have developed a high level of enthusiasm and selfconfidence (Kiss, 2016; Davis, Clayton \& Broome, 2018; Vo et al., 2018). The findings of this study also confirmed that the increase in self-confidence of the student teachers who were exposed to action research led to enthusiasm for teaching profession.

The results of this study also demonstrated that action research can assist student teachers to develop professionally in enhancing knowledge of the teaching 
profession, deepening their understanding of the professional development, and improving their enthusiasm for reflective thinking. In other words, by conducting action research during teacher training process, student teachers can be encouraged to engage in a constant reflective process in the teaching practice.

As for the implications of this study for teacher education courses, numerous benefits can be pointed out. The hallmark of a teaching professional is self-study. The student teachers in this research process were offered some occasions for implementing self-study. All those mentioned encouraging outcomes indicate that the courses in teacher training departments can be designed in accordance with such research projects to impose the sense of being autonomous on student teachers.

\section{Conclusion}

The results of this study displayed the importance of action research in teacher training process for developing reflective thinking skills of student teachers, fostering their enthusiastic attitudes towards teaching profession, and putting the theoretical knowledge into practice in a creative and self-assured way. Action research can also allow student teachers to learn by learning and develop professionally through reflection on learning and teaching as well as collaborative and cooperative participation. Additionally, exposing student teachers to action research projects during teacher training process may prepare them to conduct research in their future classrooms. It is suggested that conducting research in the classroom may build up a close relationship between teachers and students and provide teachers with further opportunities to observe their own students in the classroom.

\section{Notes on the contributor}

Muhlise Coşgun Ögeyik (PhD) is a Professor at the Faculty of Education, Trakya University. She has been working at English Language Teaching Department. She holds $\mathrm{PhD}$. degree in English Language Teaching. Her special research interest areas are: foreign language teacher training, strategy education, methodology, research design and methodology. 


\section{References}

Ado, K., (2013). Action research: Professional development to help support and retain early career teachers. Educational Action Research, 21(2), 131-146.

Bailey, K. M. (2001). Action research, teacher research, and classroom research in language teaching. In M. Celce-Murcia (Ed.) Teaching English as a second or foreign language. Boston: Heinle\&Heinle.

Borg, S. (2013). Teacher research in language teaching: A critical analysis. Cambridge, UK: Cambridge University Press .

Borg, S., \& Sanchez, H. S. (2014). Key issues in doing and supporting language teacher research. In S. Borg \& H. S. Sanchez (Eds.), International perspectives on teacher research (pp. 1-13). Basingstoke, UK: Palgrave Macmillan.

Brown, H. D. (2007). Principles of language learning and teaching. White Plains, New York: Pearson Education.

Brown, J. D. (2014). Mixed methods research for TESOL. Edinburgh: Edinburgh University Press.

Burns, A. (2013).Innovation through action research and teacher-initiated change. In K. Hyland and L. L. C.Wong (eds.). Innovation and Change in English Language Education. Abingdon: Routledge.

Burns, A. (2014). Professional learning in Australian ELICOS: An action research orientation. English Australia Journal, 29(2), 3-20.

Burns, A., \& Westmacott, A. (2018). Teacher to researcher: Reflections on a new action research program for university EFL teachers. Profile: Issues in Teachers' Professional Development, 20(1), 15-23.

Cochran-Smith, M. (2005). The new teacher education for better or for worse? Educational Researcher, 34(7), 3-17.

Cohen, L., Manion, L., \& Morrison, K. (2000). Research methods in education. London: Routledge.

Creswell, J. W. (2008). Educational research: planning, conducting, and evaluating quantitative and qualitative research (3rd ed.). Upper Saddle River, NJ: Pearson.

Davis, J., Clayton, C. \& Broome, B. (2018). Thinking like researchers: action research and its impact on novice teachers' thinking. Educational Action Research, 26(1), 59-74.

Dikilitaş, K. \& Yayl1, D. (2018). Teachers' professional identity development through action research. ELT Journal, 72 (4), 415-424.

Dikilitaş, K., \& Griffiths, C. (2017). Developing language teacher autonomy through action research. Basingstoke: Palgrave Macmillan.

Dörnyei, Z. \& Ushioda, E. (2012). Teaching and researching motivation. Great Britain: Pearson Education Limited.

Dörnyei, Z. (2007). Research methods in applied linguistics. Oxford: Oxford University Press.

Jayakumar, R., (2016). Opinion of the university teachers towards educational television programmes. American Journal of Education and Learning, 1(1), 45-52.

Johnson, K. E. (2009). Second language teacher education. New York: Routledge. 
Kemmis, S. \& McTaggert, R. (1998). The action research planner. Victoria: Deakin University.

Kiss, T., (2016). School-based teacher learning: A reflective approach. Journal of Nusantara Studies, 1(2), 50-62.

Kostaris, C., Sergis, S., Sampson, D. G., Giannakos, M. N., \& Pelliccione, L. (2017). Investigating the potential of the flipped classroom model in K-12 ICT teaching and learning: An action research study. Journal of Educational Technology \& Society, 20(1), 261-273.

Marcosa, J., Miguela, E., \& Tillemab, H. (2009). Teacher reflection on action: what is said (in research) and what is done (in teaching). Reflective Practice, 10(2), 191-204.

Mirzajani, H., B. M. Delaviz, K.M. Rajaby, R. Rezaee, S. Safoora, A.A. Kamalifar and S.H. Razaghi, (2016). Smart schools an innovation in education: Malaysian's experience. Asian Journal of Education and Training, 2(1), 1115.

Mitits, L., (2018). Multilingual students in Greek schools: Teachers' views and teaching practices. Journal of Education and eLearning Research, 5(1), 28-36.

Nunan, D. \& K.Bailey (2009). Exploring second language classroom research. Boston: Heinle.

Ryan, T. G. (2016). The pre-service educator as action researcher and leader. Action Researcher in Education, 7, 1-13.

Senior, R. M. (2006). The experience of language teaching. Cambridge: Cambridge University Press.

Stringer, E.T. (2007). Action research. Thousand Oaks, CA: Sage.

Vo, T. K. A., V. Pang \& L. Kean Wah, (2018). Teaching practicum of an English teacher education program in Vietnam: From expectations to reality. Journal of Nusantara Studies, 3(2), 32-40. 